\title{
Recent Major Fed Errors and Better Alternatives
}

\section{Allan H Meltzer}

Carnegie Mellon University, The Hoover Institution, USA

*Corresponding author: Dr. Allan H Meltzer, Carnegie Mellon University, The Hoover Institution, USA, Tel: +374 10 23-72-61; E-mail: am05@andrew.cmu.edu

Received date: January 06, 2015, Accepted date: January 19, 2015, Published date: January 26, 2015

Copyright: () 2015 Meltzer AH. This is an open-access article distributed under the terms of the Creative Commons Attribution License, which permits unrestricted use, distribution, and reproduction in any medium, provided the original author and source are credited.

\begin{abstract}
This paper discusses a central issue about the recent slow recovery. Why did enormous, unprecedented monetary stimulus have such a small response? The Fed made three major errors. It failed to recognize that the principal economic problems were real, not monetary. It focused excessively on short-term data, and failed to develop a useful strategy. And it ignored changes in money and credit, The Obama administration caused the principal real problems by imposing costly regulation, and an approach to business that the Economist called "The Criminalization of American Business."
\end{abstract}

Keywords: Monetary policy; Federal reserve; Policy errors; Banking system

\section{Introduction}

"Here, then the rulers of society have an opportunity of showing their wisdom-or folly. Monetary history reveals the fact that folly has frequently been paramount; for it describes many fateful mistakes." Knut Wicksell

Wicksell was far ahead of me in recognizing folly, but his message remains appropriate. I will mainly discuss policy folly. Since the paper criticizes the decisions and actions of the Federal Reserve let me be clear from the start that my criticisms are not personal. I do not question that the actions were taken out of mistaken beliefs and a willingness to ignore evidence, not out of malice or ill will. It is the ideas and their applications, not the people that are at issue.

Despite an accumulation of idle reserves in the financial system amounting to more than $\$ 2.5$ trillion dollars, the Federal Reserve has continued to add reserves. The chair and a majority of the open market committee claim that they act to reduce unemployment and possible deflation. I claim below that these actions compound several errors.

Alas, they are not the only errors. The open market committee overemphasizes information in very short period data-monthly and quarterly data-and gives insufficient attention to information about persistent trends. This is especially true of the neglect of growth of money and credit. It is hard to understand how a central bank can largely ignore growth of the principal aggregates that it supplies.

Also, the Board staff and principals made no visible effort to prevent the financial crisis in 2008, and we now learn that staff at the New York Federal Reserve Bank believed that Lehman Brothers was solvent and could have been supported [1]. This is directly contrary to repeated statements by the New York Fed President Geithner and Board Chairman Bernanke. In the months preceding the crises, the Federal Reserve took no actions to prevent the calamity, mainly, because it denied that a general problem would occur. But it added to the crisis in several ways including approving undercapitalized subsidiaries that held mortgage backed securities but had little equity.
And it allowed major banks to reduce required equity by holding bonds that they insured. Such actions greatly reduced the cost of risk to the banks with little equity.

The result was Congressional action that granted additional power and authority. Instead of approving the Brown-Vitter bill that would require a substantial increase in equity capital, Congress increased the rules applied to major banks. Eventually, the Board raised required equity capital, but not enough to impose strong incentives for prudence on major bankers and their principal stockholders.

The Board and the Reserve Banks employ many able professional economists. Surely there are some that remind their principals that managers and principal stockholders have much stronger incentives than regulators to prevent losses that they bear. Regulators especially in New York are likely to be "captured" by major banks and reluctant to act against them. How else can we explain the excessive payments to Goldman Sachs and others when AIG failed?

These examples introduce some of the main reasons for Federal Reserve errors, failures, and misjudgments. That said, I must add that I applaud the extreme action taken in 2008 to prevent financial collapse. That was a major effort, and it succeeded.

The rest of this paper analyzes some of the errors. A later section proposes changes that would improve policy operations and the outcome under which we all live. No one will be surprised that some of the proposals call for rule-like actions.

\section{Policy Errors}

As an historian, I am very aware that the 1913 Federal Reserve Act imposed restrictions-rules-on what the new agency could do. First, it applied the gold standard rule that an earlier Congress (1900) wrote into law. And the 1913 Congress imposed a second rule-absolutely no direct support for the Treasury by making loans to the Treasury [2]. Under that rule, it did not buy Treasury bonds. To finance World War I the Fed circumvented the restriction by making low cost loans to banks that purchased the bonds.

By the early 1920s, the Federal Reserve learned to circumvent the second rule more directly. It bought Treasury securities in the market. It could buy a new issue as soon as it came to market without violating 
the rule against direct purchase. Through most of its one hundred year history, it limited its purchases to short-term securities except during World War 2 and prior to the 1951 Accord. But it has abandoned any restraint on its purchases. It now holds several trillion dollars of Treasuries, and it has no coherent plan for reducing its balance sheet.

Goodfriend [3] analyzes recent policy as a carry trade. The Fed borrows at the short-end and lends at the long-end. By doing so, it takes on balance sheet risk when interest rates rise. The Fed will have to reduce its payments to the Treasury, recently near $\$ 100$ billion annually, when short-term rates rise above long-rates and capital losses increase. ${ }^{1}$

I praise the 2008 policy known as QE1. It prevented the collapse of the payments system by inducing expectations that banks would not fail because the Fed would work to flood markets with liquid assets to stop heightened fears of bank insolvency. What of QE2 and QE3? The threat had faded. I will share why I believe they were a mistake, compounded by other mistakes.

The biggest mistake was to conclude that the slow recovery of employment and output was a monetary problem. Much evidence suggests that, after the initial collapse, the policy problem was real, not monetary. The Fed's big mistake was failure to see that most, possibly all, of the sluggish recovery resulted from real pressures on activity, especially business investment.

After a few years of the start of the massive expansions known as QE2 and QE3, someone at the Board or its staff should have recognized that despite massive stimulus, the economic expansion was the slowest recovery of the entire postwar period. As late as 2013, Census Bureau data show median household incomes 8 percent below the previous peak, from above $\$ 56,000$ in 2007 to below $\$ 52,000$ in 2013. And only 10 million jobs had been created in the recovery. This is a dismal performance, much discussed in the media. Why did it not lead to a re-examination of the Fed's policy and administration policy? This is a clear failure that should have led to re-examination and different policies.

In a 1969 paper, James Tobin [4] developed a model of monetary transmission in which the relative price of existing assets plays a major role. In the many models, I analyzed with Karl Brunner [5], the same is true. The transmission of monetary policy affects asset prices such as prices of capital assets and real estate. The rise in the nominal asset price is also an increase in the price of existing capital relative to the replacement cost of new capital. Current investment rises following a rise in the asset price of capital and builders construct new housing and apartments. Investment, economic activity and employment rise. When monetary policy tightens, the opposite occurs. Prices of capital assets fall reducing the price of existing capital relative to new production of assets. These models show how monetary expansion changes real variables.

There is more to the transmission process in our papers, but it should be obvious that the process just described is a dominant feature of a monetary cycle. It is no less obvious that it was incomplete in this cycle. Nominal prices of existing capital market assets rose spectacularly, but investment in new capital lagged and remained sluggish.

That was a signal that the monetary transmission process was not working as it should. The Fed's error was to rely on less reliable models like the Phillips Curve or the Woodford models that ignore or severely limit the role of money, credit, and relative prices.

No less an authority than Paul Volcker explained publicly and to the staff that the Phillips Curve was unreliable and not useful. As Chair, he gave many talks about what I have called the anti-Phillips Curve. Volcker claimed repeatedly that the best way to reduce unemployment was to reduce expected inflation. He did not use Phillips Curve forecasts. He ran a very successful policy.

Alan Greenspan was less outspoken, but he also rejected Phillips Curve forecasts as unreliable. Instead of finding a better model, the staff resumed use of Phillips Curve forecasts. They were again unreliable as should be evident from the repeated prediction errors for quarterly or annual recovery. Year after year, growth and employment are below forecast.

One might hope that repeated forecast errors all in the same direction would raise doubts about the usefulness of the model or models and initiate search for a better model. This does not appear to have happened.

There are other signs that should concern economists and policymakers. I will mention two, or perhaps one and a half.

First, market data show that instead of investing in new capital, many firms are repurchasing shares after recent share price increases. Doesn't this strongly suggest pessimism about the future? Why ignore this signal?

Second, for years older men, 55 and above, have dropped out of the labor force. In this recovery, they have been joined by younger workers, 18 to 34 . I count this as a possible additional sign of pessimism about opportunities, but it also reflects the increased unemployment compensation, health, food stamps and other benefits available to untrained workers. Many of them have taken the benefits and periodically work in the underground economy. It would be useful to study the degree to which the welfare state encourages this behavior.

The reduction in labor force, like the implications of low investment among other reasons for a sluggish recovery, should point us to real problems that monetary policy cannot affect. Below, I will explore some of the real problems affecting our economy. For the present, let me emphasize that the Federal Reserve mistakenly used low interest rates and huge increases in reserves in an attempt to solve problems that were mainly not monetary. This was not just an error. I call it a series of blunders because it was repeated persistently. ${ }^{2}$

Didn't anyone question why reserves were piling up on bank balance sheets? Didn't anyone ask what more reserves could do that lenders could not do by using the existing reserves? Chair Yellen expresses concern about the number of part-time workers. Doesn't she recognize that the Affordable Care Act gives strong incentives to

1 To avoid recognizing losses, the Fed does not plan to mark bonds to market by holding them to maturity.

2 At times, the rationale included preventing deflation-a decline in a general index of prices. QE1 may have prevented deflation. The case is weaker for QE2 and disappears by the time of QE3. Even if one accepts a risk of deflation, how can hundreds of millions of dollars of excess reserves prevent deflation? Renewed concern about deflation in 2014repeats an old error, mistaking a large change in the relative price of oil as a change in the general price level. This repeats the error in the 1970s when oil prices rose. The Shadow Open Market Committee pointed out the error in 1975; The Federal Reserve recognized its error in 2000. 
employers to avoid mandatory healthcare costs by hiring part-time workers. This is a nonmonetary explanation especially relevant for retailing and food service businesses. And, of continuing interest, shouldn't the System announce a workable, contingent strategy for reducing the more than $\$ 2.5$ trillion of reserves. Failure to do so suggests the absence of a reliable strategy consistent with the overemphasis on near-term and neglect of longer-term events and actions.

Month after month the Fed focused its attention and the market's concern for the noisy monthly reported jobs growth survey. It soon became clear that the initial announcement could be revised substantially the following month. Announcements that seemed to show that employment growth had returned were often followed a month later by revisions suggesting the opposite. And, at times, the opposite occurred; slow growth of employment could become better next month. Many of the market participants, like sheep, followed where the Fed led. Neither they, nor the Fed, publicly questioned the use of such a misleading indicator while neglecting the more persistent decline in labor force participation.

When the Fed finally stopped using monthly employment growth as a principal policy indicator, it later shifted toward several other labor market variables, especially the wage rate. Does the Fed have a reliable model of real wages? Shouldn't they make it available if they do?

Can monetary policy affect real wages? Has monetary neutrality been forgotten or lost? Or is this another error?

The 1913 Act barred the Federal Reserve from purchasing government securities. That prohibition did not last, but as late as the 1950s Chairman Martin and his colleagues defended a policy called "bills only" to keep the System from intervening in long-term markets. President Plosser and some others have urged a return to that policy or something similar.

On October 1, 2014, the open market account held the following longer-term issues:

Treasury Notes and Bonds- $\$ 2.3$ trillion

Agency Mortgage Backed Securities-1.7 trillion

Total Account Holdings-4.2 trillion

95 percent of the System holdings were at medium- to longer-term. This is a clear violation of prudent policy.

At the October 2014 FOMC meeting, President Lacker, (Richmond) dissented from the decision not to sell mortgage backed securities. He recognized and acknowledged that the Fed had made the serious error of engaging in credit allocation by buying mortgage backed securities and should try to return to a more neutral policy. President Lacker also objected to the use of monetary action to finance Treasury fiscal operations. Some of the press asked me to comment.

\section{I wrote the following:}

"President Lacker is right. Since 2008 the Federal Reserve has ignored the distinction between fiscal and monetary policy. It engages in fiscal policy in several ways. One is the way President Lacker highlighted. The Fed buys a very large share of the mortgages that come to the market. This is credit allocation and fiscal policy. No previous Federal Reserve engaged in such operations, although at times the Fed bought a few mortgages.
“That's just one failing. The QE policy finances a large part of the budget deficit, and the enormous Fed holdings of government securities pay interest to the Fed. The Fed pays much of the interest to the Treasury, so a large part of the Fed's earnings go to finance the budget deficit. This, too, is a fiscal operation.

"Further, the Dodd-Frank Act put the Fed fully into credit allocation to "disadvantaged" folk. This is a replacement for government spending. It is fiscal policy financed by the monetary authority. Why did Chairman Bernanke not object? Why doesn't the Fed demand an end to the policy?

"One expects to see policies of this kind in badly run poor countries. Mature, developed countries usually refrain from such actions. The Fed is acting like the bad examples one used to find in Africa or Latin America. In the past, the Fed and others cautioned central banks not to engage in such practices. Who will caution us? Who will stop us from folly?

"Finally, the Fed fails to recognize why their massive monetary expansion and sustained zero interest rate has had little impact on unemployment. The employment problem in the US is mainly a real economic problem that is out of reach for monetary expansion."

Another Fed error, highlighted by President Lacker's dissent is the use of monetary policy for credit allocation. Mortgage market operations are now dominated by official purchases. A once vibrant market no longer exists. This is one type of credit operation discussed in Goodfriend [6], referred to earlier.

But it is not the only example of this error. Why did the Federal Reserve acquiesce without a public protest in the provision of the Dodd-Frank Act creating a credit agency called the Bureau of Consumer Financial Protection (BCFP)? Federal Reserve earnings finance this credit allocation but the Federal Reserve does not control the allocation. The new agency allocates credit to allegedly "disadvantaged" borrowers. This puts the Federal Reserve fully into the financing of political operations, without control of the choices. And it violates the provision of the United States constitution that requires Congress to appropriate all monies. The new law circumvents the constitutional requirement and opens the way to political allocation.

My reading of Federal Reserve history leads to a belief that no previous Board would have accepted this mandate to finance credit allocation. I believe BCFP reflects current inability by Congress to approve new spending programs, so they used credit allocation instead. This is a political act that sacrifices Federal Reserve independence. It further politicizes the Fed. It should be repealed promptly.

\section{Why So Many Errors?}

Many of the errors I have discussed have a common source: the Fed gives excessive attention to very short-term data, monthly and quarterly data. As a result, it lacks a strategy for achieving long-term stability of output, employment and the price level. I understand and appreciate the pressures from members of Congress, the administration, large parts of business, especially stock exchange traders, labor and others. One reason for independence is to permit Fed officials to reject these pressures. Unfortunately many of the officials share this short-term orientation. Some have told me that even if almost all the unemployment problem is real, not monetary, the Fed should work to reduce the small part that yields to their 
Page 4 of 7

efforts. And what of the longer-term consequences of expanding reserves to do that? Manage them when they appear. That's the opposite of a strategy to stabilize the economy.

The original Federal Reserve Act, as I noted at the start, relied on rules-the gold standard especially. In several papers, I have pointed out that the two periods in the last 100 years in which the Fed came closest to providing stable growth and low inflation are 1923-28 and 1986-2002. In both, the Fed more or less followed a rule, the gold exchange standard for 1923-28 and the Taylor rule from 1986 to 2002. In both periods, recessions were mild and short-lived. Discretionary policy never did as well. The closest it came was 1953-60, but that period had deeper and more frequent recessions.

Rules bring several advantages. They focus policymaker's attention on medium or long-term objectives. When they are successful, as they have been, they reduce outside pressures. Good policy prote0cts the Fed. During the years of moderation under Chairman Greenspan, Fed policy received less attention than it has in the current recovery. That increased stability.

Rules give market participants useful information about expected future policy actions. This reduces variability. The period when policy more or less followed the Taylor rule is consequently known as the years of "great moderation," because variability declined. By approximating the Taylor rule, the Federal Reserve avoided its usual mistake of shifting from one part of the dual mandate to the other. Instead it aimed at both. That increased stability.

The U.S. constitution gives Congress responsibility for money in Article 1, Section 8. The Federal Reserve Act makes the Federal Reserve the agent, but Congress retains nominal responsibility.

Congress has difficulty supervising its agent. Any person qualified to chair the open market committee can avoid formal criticisms from the House or Senate committees on monetary policy. A rule would improve oversight by giving Congress a clear standard. The House of Representatives approved a rule in 2014. It represents a start on improved policy. I believe the current, proposed rule requires too much monitoring. Its strength lies in its setting a standard-the Taylor rule-but allowing the Federal Reserve to adopt any rule it wishes. It must adopt one and explain why it does not do as well as the Taylor rule, if that occurs.

By focusing policy on longer-term objectives, a policy rule helps the Fed to achieve stability. Discretionary policy has become overly dependent on quarterly forecasts. It should not surprise anyone to be told that economics is not the science that gives accurate quarterly forecasts. There is no such science. Monthly and quarterly data have large random components. The future is always uncertain in Frank Knight's or Keynes's definitions of uncertainty.

Some argue that the Phillips Curve is the only model of real activity and inflation that economists have developed. As noted earlier, that is a false statement. The Tobin and Brunner-Meltzer models allow money growth to have temporary real effects. In several papers Professors Stock and Watson have shown that the Phillips Curve is not a reliable model of real behavior. I claim that there is no persistently reliable model of quarterly activity. The proper response to this uncertainty is to adopt a somewhat longer horizon. At annual frequency money demand is much more stable than at quarterly frequency.

\section{Prudential Policy}

The Federal Reserve came into being in part to avoid or mitigate the financial market crises that culminated in the 1907-08 financial stringency. Its history since has been marked by deep crises. Clearly, the stability of the financial system has not increased. Some would argue that it deteriorated.

The earliest regulation to induce banks to adhere to a prudential standard is named for Walter Bagehot, editor of the Economist magazine. Bagehot's rule called on the central bank to "lend freely at a penalty rate." To do so, the Bank of England had to get government permission to suspend the gold standard. Bagehot recognized that in periods of financial panic, the Bank eventually asked the government to suspend the gold standard and then lent freely at a penalty rate.

I have called Bagehot an early rational expectationist because his call for a policy announcement told bankers in advance what policy to expect, thereby permitting them to adjust their actions. The Federal Reserve has at times discussed a choice of policy, but it has never announced the crisis actions it would take. Bankers were not given information on which to form dependable expectations and incentives to guide their preparations.

Bagehot's rule did more. By calling for a penalty rate, it avoided banks using the offer of reserves as a way to borrow cheaply, as PNC Bank and perhaps others did in 2008-9. And by requiring banks to borrow against "good collateral," Bagehot's rule gave strong incentives to hold such collateral. That's another reason why the rule should be announced in advance and followed.

The original purpose of so-called prudential policy, better described as lender-of-last-resort policy, was prevention of bank runs and financial market collapse. Over time, the objective became the prevention of failures by very large banks. Over time, bailouts came to dominate policy. Small and medium-sized banks were allowed to fail; deposit insurance, paid by banks, compensated deposit holders. The public benefit was the spread of deposit banking by shifting risk from depositors to banks.

The Dodd-Frank Act substantially increased the authority and responsibility of the Federal Reserve and other banking agencies for policy in financial crises. The act claimed it avoided bailout of large banks. In fact, it gave final responsibility for bailouts to the Secretary of the Treasury, the very same officer that authorized all previous bailouts.

The Federal Reserve made the mistake of accepting responsibility for writing rules to increase financial stability. Some among them should know that the Federal Reserve had failed to require prudential policy in the years preceding the 2008 crisis. It permitted giant banks to create undercapitalized subsidiaries that acquired mortgages. Like the bankers, it failed to question the AAA rating given to many mortgage securities that subsequently went into default. The Federal Reserve banks sent numerous examiners to major banks prior to the crisis. They closely observed portfolio acquisitions. In a public forum, a chief examiner reported that the examiners did not question any of the transactions.

A former employee of the New York bank claims that the regulators are overly influenced by the large banks and reluctant to regulate them. Although the president of the New York Fed denies the charge, Federal Reserve's failure to act prudentially before the crisis seems consistent with the charge. 
The reason is the standard problem of incentives. At best, regulators incentives are mixed. Capture is real and seems to be present.

On four occasions testifying in hearings leading up to Dodd-Frank, I urged Congress to require greatly increased capital requirements that applied to the largest banks without exception or risk weights. My analysis of the much less regulated banking system in 1929-1932 showed that none of the largest New York banks failed. All held at least 15 percent equity capital. Their policies were prudent. I argued that a return to a 15 percent equity capital requirement would restore safety and soundness. Principal stockholders would force management to lend prudently.

Senator Vitter (Louisiana) picked up my idea and developed the Brown-Vitter bill with Senator Brown (Ohio). This bi-partisan bill cannot get out of the Senate Banking Committee because of strong opposition by the large banks. Some of these banks seem to prefer the present system of detailed regulation combined with too-big-to-fail. One reason is that the market has given the largest banks a competitive advantage. They borrow at a lower rate than others. Former competitors that were not considered too-big-to-fail have disappeared. Several sold out to the largest banks-J.P. Morgan Chase, Bank of America, and Wells Fargo. Loan concentration increased dramatically. The Federal Reserve presided over this reduction in competition brought on by its policy of too-big-to-fail.

One consequence of current capital standards shows the problem. Prior to the crisis in 2008, some of the largest banks reduced their equity capital by substituting prime debt. Then they insured the debt with agents like AIG. If these banks made risky loans, others-not their owners-bore the loss. This is another bad example of regulation by regulators who have little incentive to oppose bank management and much greater incentive to get along by going along.

We will not develop a safer financial system without creating and enforcing standards that provide incentives for prudent policies. Thomas Hoenig, Vice Chairman of the FDIC shows how permitting banks to use risk weights lowers effective capital standards. His paper shows that Basel III capital standards are substantially lowered by permitting risk adjustment [7].

\section{Reforming the Federal Reserve}

Two main parts of Federal Reserve operations are regulation policy and monetary policy. Both should be reformed. In performing both tasks, the Federal Reserve must be concerned to keep them working harmoniously. Current practice does not do that. Prudential policy will at times call for actions inconsistent with the goals of monetary policy. An example, one of many, occurred in the summer of 1982. Domestic and foreign bank failures required an end to the severe antiinflation policy. Despite some strong opposition at the FOMC, Chairman Volcker chose to lower interest rates. Fortunately that worked well.

\section{Prudential regulation}

My principal proposal for prudential policy is stated above. The Fed should recognize that its responsibility is to protect the public, not the banks, by safeguarding the payments system. That requires increasing required equity capital to shift potential losses to the major banks. The increase should be announced but phased in over several years. That shifts risk management and risk back to the banks. As compensation, industry should gain from a major reduction in specific regulation.
The Dodd-Frank law should be repealed, and credit allocation should cease. The Federal Reserve should return to a "bills only" policy.

By shifting attention to the payments system instead of large failing banks, the Fed would recognize that the public good requires the stability of the economy and maintenance of the payments system. It does not require the solvency of banks operated by imprudent bankers. It is a system requirement not the protection of imprudent bankers.

To further strengthen its operation as lender-of-last-resort, the Fed should announce the collateral that would be acceptable in a crisis. By pre-announcing its rule, the Fed encourages banks to hold a requisite volume of such paper in uncertain periods. And the Fed should avoid moral hazard by lending at a rate above the pre-crisis rate on the collateral. As Michael Bordo and Anna Schwartz [8] show, Baghot's rule worked reliably when the Bank of England followed it.

\section{Monetary policy}

The many errors discussed earlier show the Federal Reserve requires changes that make policy more predictable, more rule like, less politicized. This is true especially of the failure to recognize that our current real problems of slow recovery, declining participation in labor force to the lowest level in decades and increased part-time employment are not changed by expansive monetary action. The most likely reason for this persistent error is that the Federal Reserve has yielded to public and political pressures. Adopting and following a rule helps to reduce political pressures or at least to respond to them.

In a federal republic like ours, the U.S. Constitution disperses power among the three branches of government. Power to regulate money is given to Congress. The Federal Reserve is its agent. The principles governing our country are violated by the expansion that quadrupled the size of the Federal Reserve's balance sheet. No agency should have that much power unrestrained by explicit Congressional approval. A revision of the Federal Reserve Act must sharply limit the Federal Reserve's discretionary actions.

Further, does anyone believe that the uncertainty about current and future interest rates benefits the economy? Every large release appears to generate changes in the expected interest rate path. Speculators hang on the Chairman's words and most likely over-respond. This is much different from the period known as The Great Moderation when the FOMC remained rather consistent with a Taylor Rule.

More than 200 years ago, Henry Thornton warned that a monetary authority should not be beguiled by the praise from merchants and speculators who laud the initial effects of excessive monetary expansion. They cheer the rise in asset prices, as many have done recently. The more short-sighted do not look ahead to the later decline in asset prices. Their cheers encourage the rampant short-termism to which the Fed is prone.

The first reform task should be to restore some of the Fed's lost independence. Back in 1913, a common statement described the Reserve Banks as "bankers" and the Board as political. Over time, mainly in response to crises but also by the efforts of Chairman Martin, power within the System shifted to the Board, increasing opportunities for greater political influence. Over time, the Reserve Banks-most of the Reserve Banks-became less influenced by bankers and more responsive to the perceived problems in their districts. ${ }^{3}$ During the 1970s inflation, the St. Louis Bank led opposition to inflationary policies. Recent opposition to credit allocation and 
overly expansive policies was led by the presidents of Reserve Banks in Philadelphia, Richmond, Kansas City and Dallas.

In the 1920s, the presidents of the Reserve Banks chose open market policy. The Board had veto power only. Despite the Board's mistaken adherence to the real bills doctrine, the Banking Act of 1935 gave majority control of open market operations to the Board members. Reserve Bank presidents outside New York vote on policy only every two or three years.

I propose two changes. First, all presidents should vote at every meeting. Second, appointment and reappointment of presidents to their five-year terms should be the responsibility of the directors of each bank. The Board's role should be limited to objecting to appointments for cause.

The purpose of this change is to shift influence toward the general public and reduce political influence. That would be a major step toward increased independence.

Accompanying the change in the role of presidents, Congress should adopt a rule and require the Federal Reserve either to follow the rule or explain in writing why it deviated.

Independence is the absence of political influence. It is best maintained by announcing and following a rule. If it leaves the rule by declaring an emergency it must explain why. The FOMC should submit resignations together with the explanation. Congress which has constitutional authority for money can accept the explanation or the resignations. Several countries including the U.K. have adopted this requirement since I first proposed it at a meeting with the New Zealand Reserve Bank about 1985.

The Board responded negatively to the recent passage of a monetary rule by the House of Representatives. They want to retain unlimited discretion. The alternative is to restore the government of checks and balances that served well during much earlier history.

\section{Postscript: What are the Real Problems?}

My references to real problems require explanation. Many businessmen regard the current administration as hostile, overly eager to prosecute them for alleged misdeeds. As the Economist featured on its August 30, 2014 cover and said in a lengthy article the Obama administration "criminalized the American company." The article said in part (p. 21): "The problem is not just that companies are ever more frequently treated as criminals. It is that the crimes they are accused of are often obscure and the reasoning behind their punishments opaque, and that it is far from obvious that justice is being done and the public interest is being served."

Given the high cost of proceeding to trial and the uncertain outcome of that course, businessmen settle out of court, admitting guilt and pay a fine. The Economist (p. 22) quotes a recent article in the Harvard Law Review. "Public enforcers often seek large monetary awards for self-interested reasons divorced from the public interest in deterrence. The incentives are strongest when enforcement agencies are permitted to retain all or some of the proceeds of enforcement."

The costs and uncertainty that result discourage investment. Greatly increased government regulation adds to the corporate burden by raising costs and increasing the uncertainty of returns. As one example the Dodd-Frank Act, according to one count, imposed 398 new regulations to an already heavily regulated industry.

Regulation is like an increase in taxation. Meltzer and Richard [9] show that, in a general equilibrium model, increasing tax rates widens the spread in the income distribution between upper and lower incomes. Evidence from the U.S., Great Britain, and France supports the model. The dynamic model supports the claims made by Kuznets.

Banking and finance are one example. Regulation to strengthen labor unions, regulate pollution, and control many business practices add to the intense disincentives acting like a tax on success. And the administration shows little interest in reducing the corporate tax rate and paying for the reduction by closing so-called loopholes-special provisions.

Porter and Rivkin [10] asked 10,000 Harvard Business School alumni about why they did little investment. The respondents are officers at major U.S. companies. The article summarized the replies. The answers listed real factors, not money or interest rates. Among the responses were an ineffective political system, weak public education, complicated regulation, deteriorating infrastructure, and a lack of skilled labor.

Reducing burdensome regulation would reduce costs and shift resources to more productive uses. Repeal of regulations that increase rewards for not working and elimination of incentives to hire parttime workers would increase employment. Adopting a fundamental reform of the budget process that gradually eliminates the unsustainable current and future budget deficits without large tax increases is a vital step to increase economic growth.

Currently, we see instead claims that we face "secular stagnation." That term originated in Alvin Hansen's 1938 presidential address to the American Economic Association. His Harvard colleague Joseph Schumpeter responded by predicting continued growth in Capitalism, Socialism, and Democracy. Growth surpassed Schumpeter's optimistic prediction.

In 1938, the problem was failure after New Deal policies. In 2014, it is again the failure of mistaken administration policy. The Federal Reserve's errors are (1) failure to recognize the reason for slow growth, and (2) a mistaken belief that adding more reserves can make consumers and business optimistic.

Add to the real problems, the decline in growth elsewhere in the world. Federal Reserve policy cannot offset that real effect, but improved real policies could increase investment and domestic expansion.

During the Reagan years, the Federal Reserve first produced a recession and then a strong recovery. This was a monetary cycle. Contrast the current cycle. The Federal Reserve contributed to but did not cause the contraction, and it cannot produce a Reagan-like (or Volcker-like) recovery. In that recovery, with relatively high real interest rates of 6 to 7 percent in 1983 and 1984, tax cuts, and animal spirits created 17 million jobs during the 1980s. Unlike the current recovery, unemployment by blacks dropped 2.8 percentage points. Black household income rose 84 percent.

Opportunities for blacks followed from a policy very different from current policy of increasing transfers, anti-business actions,

3 The biggest exception is the New York Bank. It often serves as representative of the larger banks and the money market. See, for example, the charges made recently on National Public Radio. 
burdensome regulation and taxation. The administration must recognize that the Reagan policies worked much better. And the Federal Reserve should recognize that they cannot do much if anything about real problems. After its good response to financial failure, the Federal Reserve has made multiple errors that suggest strong political pressure either internally, externally, or both.

Our economic problems will continue until a pro-growth policy replaces the current fiscal and regulatory policy. Business investment will not revive until businessmen see more reason for optimism. That may begin to happen as the current administration becomes more of a lame duck that cannot continue to increase costly regulation.

\section{References}

1. Stewart, James B, Eavis, Peter (2014) "Revisiting the Lehman Brothers Bailout That Never Was," New York Times, USA.

2. Garbade, Kenneth D (2014) "Direct Purchases of U.S. Treasury Securities by Federal Reserve Bank,” Federal Reserve Bank of N.Y., USA.
3. Good friend, Marvin (2014) "Monetary Policy as a Carry Trade," unpublished, USA.

4. Tobin, James (1969) "A General Equilibrium Approach to Monetary Theory." J of Money, Credit and Banking 1: 15-29.

5. Brunner, Karl, Meltzer, Allan H (1968) "Liquidity Traps for Money, Bank Credit and Interest Rates," Journal of Political Economy 5: 1-38.

6. Goodfriend, Marvin (2014) "Lessons from a Century of Fed Policy: Why Monetary and Credit Policies Need Rules and Boundaries." Journal of Dynamics and Control, in press.

7. Hoenig, Thomas M (2013) Basel III Capital: A Well-Intended Illusion," multilithed, Washington, USA.

8. Bordo, Michael, Schwartz, Anna J (1999) "Monetary Policy Regimes and Economic Performance: The Historical Record," John Taylor and Michael Woodford, Handbook of Macroeconomics, Amsterdam: North Holland Publishers.

9. Meltzer, Allan H, Richard, Scott (2014) "A Positive Theory of Economic Growth and the Distribution of Income", unpublished.

10. Porter ME, Rivkin JW (2012) "The Looming Challenge to U.S. Competitiveness." Harvard Bus Rev 90: 54-61. 